\title{
Analysis of the presence of Anglicisms in a Spanish internet forum: some terms from the fields of fashion, beauty and leisure
}

\author{
Carmen Luján García \\ Universidad de Las Palmas de Gran Canaria \\ carmen.lujan@ulpgc.es
}

\begin{abstract}
The pervasive presence of English in Spain is unquestionable; indeed, a vast volume of literature has provided evidence of this fact. In this article, the remarkable presence of Anglicisms in a particular type of social media will be examined, namely the Spanish Internet forum enfemenino. The analysis covers three specific domains: beauty, fashion and leisure. The study focuses on a sample of English borrowings used in news articles published in this forum over the last 2 years (from January 2015 to March 2017). The findings reveal an increasing use of pure Anglicisms in the forum, whereas adapted Anglicisms, along with pseudo-Anglicisms, are not so common. These Anglicisms seem to be used for different reasons: the values of modernity and prestige associated with English, the lack of Spanish equivalents in some cases, the emergence of new concepts and innovations and, last but not least, the increasing influence that the Anglo-American culture is exerting on Spain. This raises the question of the extent to which these factors affect our sense of identity in Spain.
\end{abstract}

Keywords: Anglicisms, Fashion, Beauty, Leisure, Internet, Forum, Spanish

\section{Introduction}

The fact that English has spread as the main global language has led to question the traditional role of English merely as a foreign language (Graddol, 2006). As a consequence of this fact, we can witness the remarkable presence of Anglicisms in a 
variety of languages. This expansion of English has led to the emergence and development of multiple varieties around the world, where they may be used as first, second or foreign languages. As a logical result, rather than speaking of a single English language, we can use the term "Englishes", which was coined to refer to this set of varieties more than two decades ago by Kachru (1992: 357).

Scholars such as Görlach (2002), Anderman and Rogers (2005), Fischer and Pułaczewska (2008), De Houwer and Wilton (2011); Furiassi, Pulcini and RodríguezGonzález (2012); Furiassi and Gottlieb (2015); Andersen, Furiassi and Mišić Ilić (2017) have provided insights into the contact of English with different European languages over recent decades, a period in which the influence (not to call it "invasion") of the English language has pervaded almost every single area of daily life.

This piece of research focuses on the lexical influence of English on a Spanish Internet forum. Some previous publications have dealt with the presence of English in various fields of Spaniards' daily life. For instance, Rodríguez González (2012), Campos (2015) and Rodríguez Medina (2016a) examined the use of Anglicisms in areas such as sports; López-Zurita (2005) showed the importance of Anglicisms in economics. Advertising and TV commercials were also investigated by Rodríguez Díaz (2011) and García-Morales, González-Cruz, Luján-García and Rodríguez-Medina (2016); the fields of eroticism and sexuality were studied by Rodríguez-González, 2011, who includes many Anglicisms in his dictionary, and Crespo-Fernández and LujánGarcía (2013; 2017); other studies dealt with the employment of Anglicisms in toy leaflets aimed at young children in Spain (Luján-García, 2011) or teenagers in Las Palmas de Gran Canaria (González Cruz, Rodríguez-Medina and Déniz, 2009).

The use of Anglicisms in the realms of fashion, beauty and leisure will be examined in this article. As previous studies have revealed, these fields are very likely to involve the use of Anglicisms, since the employment of foreign words provides a sense of exoticism, innovation and even creativity; in addition, all of these values are generally associated with the examined domains, namely fashion, beauty and leisure: for instance, Balteiro and Campos (2012) researched the employment of false Anglicisms in the fields of fashion and beauty, proving that in these sectors the influence of English is apparent (Balteiro and Campos, 2012: 239). After having examined 36 pseudoAnglicisms, these authors concluded that:

the prestige and attraction of English leads speakers to follow what they consider an acceptable trend not only in terms of what they have received from English, but also through parallel coinages; the only justification for which probably is their "Englishness" that is, the iconic power of English as a trendsetter (Balteiro and Campos, 2012: 249).

Other pieces of research that have dealt with fashion-related topics may also be referred to: Rodríguez-Medina (2016b) also studied the use of Anglicisms in TV commercials of cosmetics, hygiene and personal care products. This author analysed 531 TV commercials across four Spanish TV channels (Tele5, Antena3, LaSexta and Disney Channel) and she found that: 
[t]he results confirm a considerable presence of pure Anglicisms, English-Spanish code switching, pseudo-Anglicisms and Anglo-American imagery and music in the advertising of products related to cosmetics, hygiene and personal care on Spanish television (Rodríguez-Medina, 2016b: 157).

González-Cruz (2015) explored the use of Anglicisms in several leisure fields: technology, entertainment, and food and drinks in the TV commercials of three Spanish TV channels: she found that the English language and the Anglo-American culture have a great impact on the Spanish language and culture with regard to leisure-related topics. Díez-Arroyo (2016) focused her research on ten special issues of fashion magazines, including Elle, Hola, Telva and Vogue among others, published between March and September 2013 and she asserted that:

Spanish fashion magazines regard stylistic choices as a persuasive strategy to reach and appeal to their wide readership. Journalists have found in Anglicisms the perfect elements to perform this rhetorical function (Díez-Arroyo, 2016: 38).

The means of communication that will be examined in this article is the Internet forum www.enfemenino.com. It is beyond doubt that Europeans use the Internet on a daily basis, and their exposure to this means of communication is not only work-related, but it is also used as a source of entertainment. Discussion forums are a perfect way to interact with other people, as well as to share or exchange information and publish news, among other activities. Despite the numerous studies that have been referred to above, so far not many pieces of research have focused on the analysis of Anglicisms in the particular context of Internet forums: for instance, Garley and Hockenmaier (2012) reported on the use of Anglicisms in a German hip hop forum; Zhang (2015) examined multilingual creativity in a Chinese microblog, Shanghai Release, involving English among other languages; Crespo-Fernández (2015) examined the use of taboo and euphemistic words in some Internet forums; Tagliamonte (2016) has recently studied the linguistic uses of the Internet by North American youth focusing on different linguistic aspects, such as acronyms and intensifiers. All these studies have contributed to shedding some light on this fascinating field of research, which is constantly developing as social media technologies expand in the contemporary world. New trends and ways to interact online emerge daily, and in Tagliamonte's and Denis's (2008: 27) words, "[a]ll these provide yet-to-be-discovered venues in which the foremost commodity is language".

This study intends to bridge a gap in the literature by analysing Anglicisms in a Spanish Internet forum, especially focusing on their use in the domains of fashion, beauty and leisure. The initial hypotheses are the following:

- the specialized language of fashion, beauty and leisure tends to include Anglicisms as a resource to attract the audience and provide a sense of modernity and coolness to forum users; 
- pure Anglicisms, namely English borrowings that have not undergone any kind of adaptation to the recipient language - Spanish, in this case, are the most frequently employed in the examined fields;

- fashion is probably the area with the largest use of all the Anglicisms examined.

The main objectives of this analysis intend to provide a reply for the following research questions:

- What type of Anglicism (pure, adapted, false or hybrid) is the most frequently employed in the examined Spanish Internet forum?

- In which subject area (fashion, beauty or leisure) is the use of Anglicisms most prolific?

\section{Methodology}

The methodology employed in this analysis is based on a careful reading of each news article published in an online forum. After that, a manual compilation of those posts which contained any kind of Anglicism was carried out. Therefore, the collection of the sample was quite laborious, but this process was considered to be the most appropriate and accurate. Once the sample was compiled, Anglicisms were selected and examined using the following method: firstly, the different types of Anglicisms encountered were classified according to the categorisation that will be presented in the following lines of this section, and, secondly, the domain in which the Anglicisms were used was identified with reference to the context of the post as a whole. The three domains that were distinguished were fashion, beauty and leisure.

Some Anglicisms were used more than once in the same news article, therefore, not only the variety but also the frequency of use of the chosen Anglicisms is examined and displayed in the tables present in the appendix (see Tables 4, 5, 6 and 7). Quantitative and qualitative analyses are presented in section 3.

The forum chosen for this analysis was enfemenino, available at www.foroenfemenino.com, whose main audience and participants are made up of women, as its name suggests. However, contributions are not restricted to the female gender - men can also take an active part in it. This forum belongs to the international group aufemininS.A. a media company majority-owned by German media group Axel Springer.According to data offered by this website in March 2017, this group had more than 14 million readers and had 420 million pageviews in the U.S. alone in January 2017.

The contributions to this forum are in Spanish, and its team publishes articles about fashion, beauty, leisure, society, cooking, weddings, home, travelling, cinema and TV, and games. In this study, the focus is on some of these sections, namely fashion, beauty and leisure; In addition, rather than analysing the contributors' posts, this piece of research focuses on the regular publications by the journalists or contributors from the Spanish-speaking team of this website. The period of compilation of the corpus ranged 
from $1^{\text {st }}$ January 2015 to $31^{\text {st }}$ March 2017, which encompasses a period of two years and three months.

As above mentioned, this piece of research focuses on the analysis of Anglicisms in some particular domains, so for the purpose of this research, an Anglicism is defined as any term that is directly borrowed from English. Different categorisations of Anglicisms have been suggested (Alfaro, 1970; Lope Blanch, 1977; Pratt, 1980; Lorenzo, 1987), but the most recent one is by Furiassi, Pulcini and Rodríguez-González (2012). Their widely accepted typology distinguishes adapted, non-adapted/pure Anglicisms, false/pseudo-Anglicisms, hybrid Anglicisms and calques. However, in the context of this study, this categorisation must be adapted to suit the corpus compiled. Consequently, in this study the following types of Anglicisms are considered:

Non-adapted or pure Anglicisms: direct Anglicisms including "a word or a multiword unit borrowed from the English language with or without minor formal or semantic integration, so that it remains recognizably English in the recipient language (RL)" (Pulcini et al., 2012: 6).

Adapted Anglicisms: words or multi-word units borrowed from English with orthographic, phonological and/or morphological integration into the structures of the RL. Both terms, the source language (SL) term and the recipient language (RL) term, are close in meaning (Pulcini et al., 2012: 7). Therefore, adaptations tend to affect the morphology rather than the meaning of the words.

False or pseudo-Anglicisms: the definition of false or pseudo-Anglicism considered for this analysis is the following:

a word or idiom that is recognizably English in its form (spelling, pronunciation, morphology, or at least one of the three), but is accepted as an item in the vocabulary of the receptor language even though it does not exist or is used with a conspicuously different meaning in English (Furiassi, 2010: 34).

Hybrid Anglicisms: a mixture or combination of two words from different languages, one being necessarily English.

In the following lines, the compiled list of Anglicisms is broken down according to the three different subject areas investigated: fashion, beauty and leisure. It is worthwhile to clarify that, in some cases, it is difficult to set clear-cut boundaries between beauty and fashion. The following criteria are applied in order to distinguish these three different semantic fields:

1) fashion Anglicisms include Anglicisms related to clothes, trends, kinds of garments and shoes, accessories and home decoration;

2) beauty Anglicisms encompass Anglicisms related to beauty treatments, hairstyle, make-up and nail decoration;

3) leisure Anglicisms include Anglicisms related to free-time activities and hobbies. 


\section{Findings}

This analysis initially focuses on the breakdown of the different types of Anglicisms listed in the previous section. Firstly, a quantitative analysis will provide general figures and, after that, a qualitative analysis will examine the findings in detail. In the appendix, Tables 4, 5, 6 and 7 display all the Anglicisms under scrutiny in this analysis.

Table 1 below summarises the frequency and percentage of the different types of Anglicisms detected in enfemenino during the examined period.

\begin{tabular}{|c|c|c|}
\hline TYPES OF ANGLICISMS & FREQUENCY & $\mathbf{\%}$ \\
\hline Non-adapted or pure & 66 & 83.5 \\
\hline Adapted & 3 & 3.8 \\
\hline Pseudo- or false & 8 & 10.1 \\
\hline Hybrid & 2 & 2.6 \\
\hline Total & 79 & 100 \\
\hline
\end{tabular}

Table 1: Types and frequency of Anglicisms in enfemenino

When it comes to the frequency of the Anglicisms compiled in the sample, it was found that most of them are only used once, twice or three times. However, there are a few that are used with a higher frequency. This is the case for the following Anglicisms, listed in Table 2.

\begin{tabular}{|c|c|c|}
\hline ANGLICISMS & FREQUENCY & $\mathbf{\%}$ \\
\hline look & 47 & 58 \\
\hline afterwork & 11 & 13.6 \\
\hline celebrities/celebs & 11 & 13.6 \\
\hline dot eyeliner & 7 & 8.6 \\
\hline phubbing & 5 & 6.2 \\
\hline Total & $\mathbf{8 1}$ & $\mathbf{1 0 0}$ \\
\hline
\end{tabular}

Table 2: The five most frequent Anglicisms in enfemenino

The reason why look is by far the most frequently used Anglicism could be due to the fact that there is a special weekly section in the analysed forum which deals with the worst look of the week. In second position, there are afterwork and celebrities/celebs, both of them representing $13.6 \%$ of the total number of the five most frequent Anglicisms. Dot eyeliner is in fourth position, with $8.6 \%$, and in the fifth and last position ranks phubbing, with $6.2 \%$.

Table 3 breaks down the different Anglicisms used within the three examined domains. This table also provides the frequency of use of Anglicisms within these three domains. 


\begin{tabular}{|c|c|c|c|c|}
\hline DOMAIN & VARIETY & \% & FREQ. & \% \\
\hline fashion & 34 & 43.6 & 100 & 49 \\
\hline beauty & 23 & 29.5 & 49 & 24 \\
\hline leisure & 21 & 26.9 & 55 & 27 \\
\hline Total & $\mathbf{7 8}$ & $\mathbf{1 0 0}$ & $\mathbf{2 0 4}$ & $\mathbf{1 0 0}$ \\
\hline
\end{tabular}

Table 3: Different Anglicisms and frequency of Anglicisms by domain in enfemenino

Figure 1 below shows the different Anglicisms in the domains of fashion, beauty and leisure.

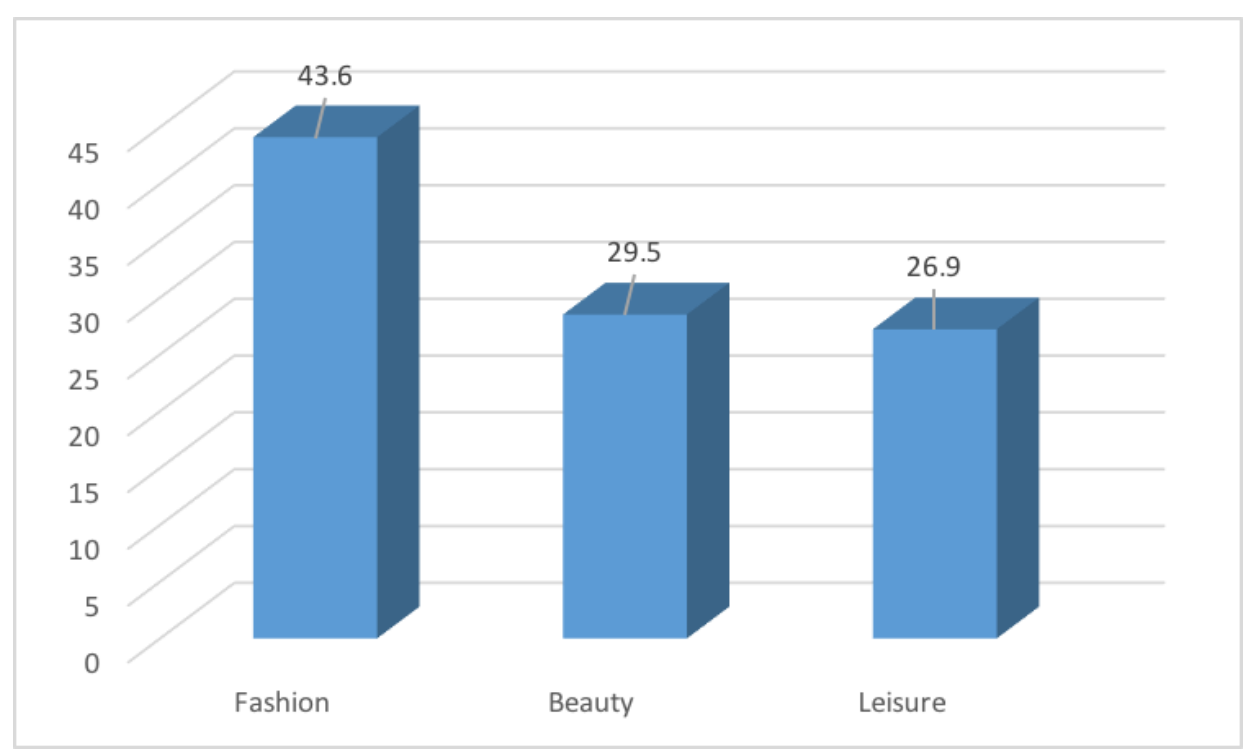

Figure 1: Different types of Anglicisms in fashion, beauty and leisure

As shown in Table 3 and Figure 1, the domain of fashion is the one with the largest variety of Anglicisms with $43.6 \%$ of the total, beauty being in second position with $29.5 \%$ and leisure in the third and last position with $26.9 \%$. Figure 2 shows the frequency of use of Anglicisms in the examined domains. 


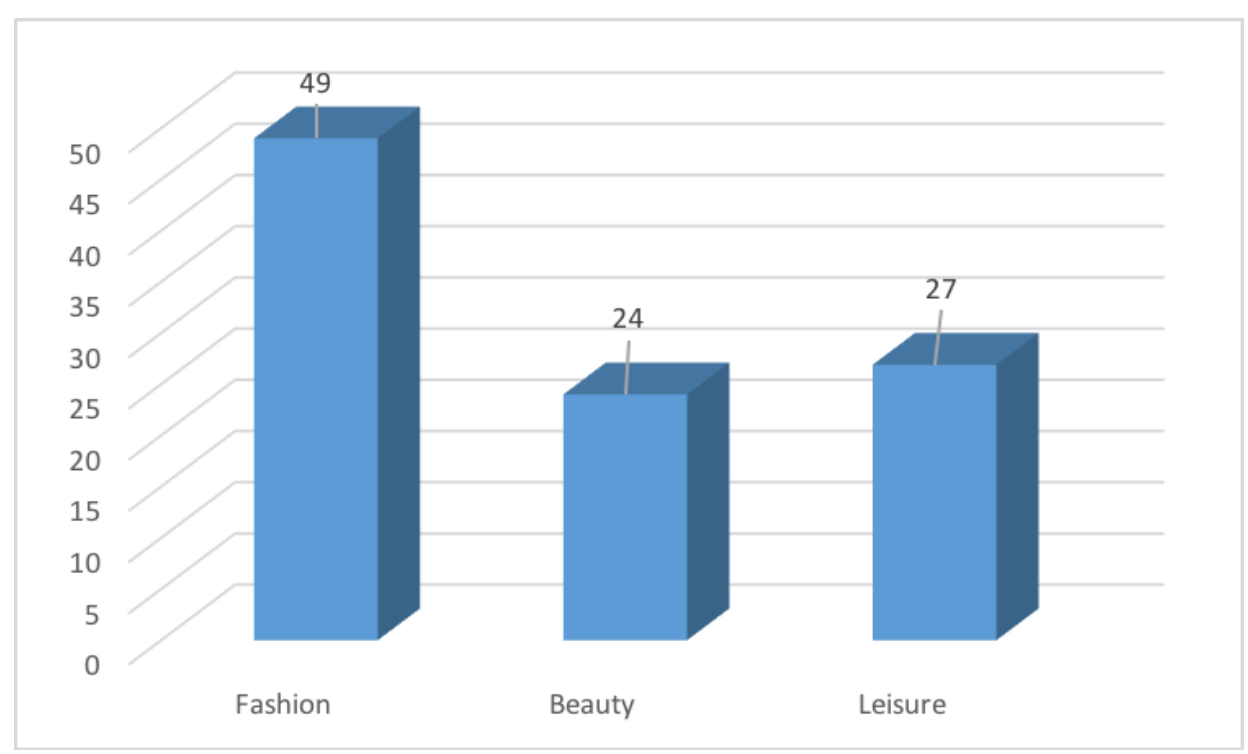

Figure 2: Frequency of Anglicisms in fashion, beauty and leisure

As Table 3 and Figure 2 display, when it comes to the frequency of Anglicisms by domain, fashion is again in first position, with a total of 100 occurrences, i.e. 49\%, followed by leisure items, with 55 occurrences, i.e. $27 \%$, and eventually beauty-related terms, with 49 occurrences, i.e. $24 \%$.

It should be mentioned that Anglicisms are used in a variety of ways in the Spanish forum examined. In some cases, Anglicisms are placed between inverted commas; at times italics is used; in other cases, no particular punctuation or font is used. For example, the term baking occurs in italics, as shown in the following example.

(1) Por ello, cuando oímos que había un nuevo método de maquillaje llamado baking, nos temimos lo peor y nos imaginamos a mujeres "horneando" su cara para verse más guapas (21/07/2015).

On the contrary, the term candy is placed between inverted commas in order to highlight that it is a foreign term, as shown in the following example.

(2) El estilo nórdico es el que más se presta a adoptar estos tonos y es que la combinación de los básicos blanco y negro con los "candy" da como resultado unos ambientes perfectos y muy acogedores $(05 / 11 / 2015)$.

As anticipated, there may be Anglicisms that are not marked at all. These are the cases of outfit and look in the followingexample:

(3) Entre ellas encontrarás a Paris Hilton con un look de exploradora, a Elle Fanning con su outfit para el gimnasio o a Zoe Kravitz con una elección que no le favorece. ¡Echa un vistazo! (17/03/2017). 
This lack of consistency in terms of devices used to highlight the foreign nature of these foreign lexical units reveals that many of the examined Anglicisms are not totally assimilated $^{1}$ in Spanish.

In the following lines, a qualitative analysis will be carried out to examine in depth some of the Anglicisms found in the sample. Despite the fact that in the appendix an example of the use of these Anglicisms in context is provided, some more examples will be presented in the subsequent sections. The Anglicisms included in these examples are marked in bold type with the aim of highlighting their use, but they do not necessarily occur in bold in the original post, as commented in the previous lines.

\subsection{Pure Anglicisms (66 cases)}

The following list of pure or non-adapted Anglicisms compiles a total of 66 examples, some of which present different spellings.

After party, baking, beauty, beauty youtubers, candy, celebrity/celebrities/celebs, checkout, chokers, clown contouring, cookies, cottage, contouring, dot eyeliner, dress code, eyeliner, foodie, front row, gif, girls' night out, gloss, glowing hair, greenery, grills, holographic lips, influencer, in-flight, jeans, layering, look, makeup, mix, nail art, nude, outfit/outfits, over size, performance, phubbing, piercing, pink lady, pink lips, pop-up stores, rainbow food, rainbow hair, rainbow freckless, reality, room service, sane food, selfie, sexy, shopping, shorts, skyline, slim, slip dress, soft, spa, streetstyle, sweet, teenager, tip, top, trendy, tweed, welcome pack, wire nail, and working girl.

The case of after party can be regarded as a spaced compound, since it is written with a space between the preposition after and the noun party. The Anglicism beauty is also noticeable, since there is a direct equivalent in Spanish for this term, namely belleza, but in four cases the English word is chosen, as shown in the following post.

(4) Y si hoy no sabes cómo maquillarte, pregúntale a nuestro test y él te resolverá todas tus dudas beautyen un solo click (03/01/2017).

Candy is another lexical unit that deserves some attention, as it refers to a decorating style involving a mixture of different colours, frequently related to hair or even walls, as in the following example.

(5) El estilo nórdico es el que más se presta a adoptar estos tonos y es que la combinación de los básicos blanco y negro con los "candy" da como resultado unos ambientes perfectos y muy acogedores. $(05 / 11 / 2015)$.

Celebs is another remarkable case as it is the widely accepted abbreviation of the English term celebrities:although it is a variant of the same word, it has been counted as an Anglicism per se. The term celebrity and its plural form celebrities, along with the abbreviated form celebs, is one of the most frequently used, and it refers to famous 
people who are able to influence and even change fashion and beauty trends. Obviously, in Spanish there is the equivalent famosos, but in the area of fashion, the English term is sometimes preferred, since it provides a sense of modernity and coolness that the Spanish term does not have.

(6) Las Semanas de la Modamarcan las tendencias de la nueva temporada y dejan a su paso un montón de looks de celebrities que pasarán a la historia (24/02/2017).

Contouring is a style of makeup, first used by Kim Kardashian, which slims down the face by using different tones on the skin. The following examples, 7 and 8, provide evidence of the context in which the Anglicism is used.

(7) A new style, called clown contouring, has emerged.Después de la fiebre del contorneado que inició Kim Kardashian hace un par de años, y del nuevo método del clown contouring(21/07/2015).

(8) Ahora esta tendencia ha dado un paso más, el llamado clown contouring, nada más y nada menos que incluir colores llamativos a tu maquillaje, y divertirte maquillándote como si fueras un payaso, de ahí su nombre. El proceso de maquillar puede resultar muy tedioso, así que ¿por qué no divertirse mientras le das forma a tu cara? Aunque a primera vista pueda parecer una locura, el resultado de este clown contouring es asombroso, ya que tras difuminar los dibujos, el maquillaje tiene multitud de matices (16/07/2016).

Dot eyeliner is a new trend in makeup, which consists of drawing a small dot in the line of the eyelashes. Example 9 shows a post in which this term is used.

(9) Emma Roberts nos tiene acostumbradas a ser una fiel seguidora de las últimastendenciastanto en el mundo beautycomo en el mundo de la moda así que, no nos ha sorprendido en absoluto que haya comenzado a usar el dot eyeliner (31/01/2017).

Foodie is an informal epithet used to talk about a person who is fond of food. It has become popular in Spanish, probably after the growing interest in TV shows dealing with food, such as Masterchef, just to mention one example.

(10) Este artículo es para ti, querida amiga foodie (27/01/2017).

Look is one of those Anglicisms which have been accepted and included in the Diccionario de la Lengua Española (DLE) and Diccionario Panhispánico de Dudas (DPD). It is quite widespread, as has been used in Spanish for a long time. According to Rodríguez González (2017: 612), this term started being assimilated in Spanish towards the middle of the last century: despite the existence of the equivalents imagen and apariencia, this Anglicism is quite frequent in Spanish. That is the reason why this lexical unit shows the highest frequency of use.

The following examples 11 and 12 provide evidence of the use of look in some posts. 
(11) Tenemos que hablar seriamente del look de Lena Dunham en la fiesta de despedida de la serie Girls (10/02/2017). [...] Esta vez y a pesar de la gran pérdida de peso por la que está pasando, no le hemos encontrado la gracia a su look (10/02/2017).

(12) Kendall Jenner se viste como Caperucita blanca para salir de fiesta por Londres y añade un diente de oro para completar un look horrible (24/03/2017).

Phubbing is a neologism in English, a blend of phone and snubbing, meaning 'the practice of ignoring one's companion or companions in order to pay attention to one's phone or other mobile device' (OLD). This term was first attested in 2012 coined by an Australian advertising agency as part of a marketing campaign with the Macquarie Dictionary; the next example (13), shows how this lexical unit has been very rapidly introduced into Spanish. In our list of examples, phubbing is attested in 2016, so in a period of four years, the term is being used in Spanish.

(13) Phubbing, la tendencia que practicas sin darte cuenta y que pone en peligro tus relaciones. Podríamos decir que en la última semana has sufrido al menos dos o tres casos de phubbing sin saber que estaban teniendo lugar (22/08/2016).

Outfit is an Anglicism that may replace the Spanish terms ropa or vestimenta. The English term is endowed with fashionable nuances, as shown in examples 14 and 15:

(14) Natalia Vodianova ha cometido un crimen estilístico esta semana. Descubre quién es el culpable de que la modelo vistiera de esta guisa y por qué nos ha defraudado tanto su outfit $(27 / 01 / 2017)$.

(15) Entre ellas encontrarás a Paris Hilton con un look de exploradora, a Elle Fanning con su outfit para el gimnasio o a Zoe Kravitz con una elección que no le favorece. ¡Echa un vistazo! (17/03/2017).

Outfits, in the plural form, is also used in English as a direct translation of las prendas, as shown in example 16.

(16) ¡llega el momento de preparar los outfits! (03/01/2017).

After having examined in detail some examples of pure Anglicisms, it could be asserted that this is the type where most cases have been found. A recent piece of research by García-Morales et al. (2016) demonstrates that pure Anglicisms, without any kind of adaptation, are used more frequently than other types (adapted, false, hybrids, calques, among others) in Spanish.

3.2. Adapted Anglicisms (2 cases) 
The terms in this category have all undergone some kind of adaptation in Spanish. Indeed, climax (E.< climax), and tartán (E.< tartan), both show orthographic adaptation.

Firstly, in the case of climax a stress mark on the vowel $-i$ is added to adapt the term to Spanish graphemic conventions. In the case of tartán (E. $<$ tartan), which is a style of cloth of Scottish origin with a pattern of different coloured straight lines crossing each other, an adaptation may be observed, since a stress mark is added to the last $-\dot{a}-$, as Spanish words ending in $-n$ require. See example 17.

(17) Tartán pero en total look (20/08/2015).

\subsection{Pseudo-Anglicisms (8 cases)}

The use of Pseudo-Anglicisms seems to be common in the field of fashion journalism and motivated by stylistic purposes, i.e. to have an impact on the audience (Furiassi, 2010: 62).

Afterwork, bombers and its stressed variety bómber, fashion, reality, teenager, short and sport are included in this category. These examples may be regarded as false Anglicisms since they do not exist in English, at least with the meaning in which they are used in Spanish.

The term afterwork, used in eleven cases in the examined corpus, is frequently employed in Spanish to refer to that drink that you have with your work mates after work and with the intention of getting to know other workmates a step further from the job context. Whereas in English afterwork is used as an adjective, in expressions such as "after work drinks", in Spanish it is used as a noun: this borrowing could be regarded as a metonymic semantic change in Rodríguez-González's (2013: 135-136) classification of pseudo-Anglicisms, since its meaning has been extended to the afterwork club or bar where people meet their colleagues. Example 18 shows the use of this term in context:

(18) Organizar un afterwork con tus compañeros de trabajo puede resultar súper positivo a la hora de estrechar la relación con ellos. Los afterwork tienen la maravillosa capacidad de hacernos mucho más llevadera la semana, lo prometemos $(02 / 12 / 2015)$.

The reason why the borrowing bómber is considered a pseudo-Anglicism is because the actual English form is bomber, a noun used with an adjectival function that usually modifies the noun jacket, as in bomber jacket. In Spanish, bombers is the plural of bomber, meaning bomber jackets; in English bombers refers to any animate or inanimate object that can carry bombs, e.g. bomber airplanes. This style is inspired in the design of the jackets that pilots used to wear during World War II. As shown in posts (19) and (20), both spellings are used in the examined posts: bomber and bómber.

(19) Lleva tu bómber como Gigi Hadid y Kendall Jenner (08/02/2017). 
(20) Calcetines de rugby, bombers, sweaters y abrigos acolchados te vestirán de arriba abajo $(29 / 07 / 2016)$.

Fashion has been included in this category of false Anglicisms, as is used as an adjective rather than a noun, as in the example reported (21), being the real English equivalent 'fashionable'.

(21) La Kardashian Jenner más fashion, sencilla y natural ha vuelto a meter la pata $(24 / 02 / 2015)$.

Reality is used in the examined posts as the elliptical form of the English compound term reality show, as the following example (22) displays.

(22) Tras el éxito de su reality, mamá Jenner no quiso dejar pasar la ocasión y materializó la belleza de sus hijas mayores (14/06/2016).

Another case is represented by teenager, which is employed as the English adjective teenage, as in the following illustration (example 23).

(23) Todo muy teenager, para tener contento a su público. (14/06/2016)

Short, without the final $-s$, is used to talk about shorts or hot pants. In Spanish, this use is quite common, whereas in English short is just an adjective. Example 24 provides evidence of this use.

(24) No podría faltar el ya mencionado short en satén fucsia, la camisa estampada, la cazadora de ante con mangas de pelo... (28/10/2016).

The false Anglicism sport is employed in Spanish to refer to a sporty style. Indeed, in Spanish this noun is often used with the function of the English adjective sporty, as shown in example 25.

(25) Eso sí, hay que tener en cuenta el diseño porque si es muy sport serán más adecuadas para looks informales $(09 / 02 / 2017)$.

Beautiful box, which is not included in the analysis as it is a proper noun, despite not being part of the study, is a marked case which is used as a proper noun, and it refers to a parcel that any subscriber will receive monthly for less than 15.90 Euros, would indeed be considered a false Anglicism. It contains beauty products and it is aimed at women of all ages. In Spanish, the expression beauty case (not present in this study) is also used as a pseudo-Anglicism. Instead, in English the term which is used is vanity case (Furiassi, 2010; Balteiro and Campos, 2012).

(26) Si deseas suscribirte a Beautiful Box pero estás esperando la mejor oferta, estás de enhorabuena. Descuento de un 5\% en tu Beautiful Box (01/01/2016). 
As Rodríguez-González (2013: 147) reports, many pseudo-Anglicisms are relatively well-established in Spanish, and that is the reason why they have been included in different dictionaries. This is the case for short and sport, both of them present in this study and recorded in the Diccionario de la Lengua Española (DLE) and the Diccionario Panhispánico de Dudas (DPD).

\subsection{Hybrid Anglicisms (2 cases)}

Country chic is an English-French hybrid, which is used to refer to a particular style. Example 27 illustrates this combination of the English term country and the French word chic.

(27) Piezas chics que construyen los detalles de este estilo evocando los ambientes más románticos y bucólicos acercándose incluso al country chic (18/08/2015).

Ombre lips is another instance of hybrid Anglicism since it combines the French term ombré with the English term lips. Examples 28 and 29 provide evidence of this hybrid in context.

(28) ¿Eres de las que no sale de casa sin llevar los labios pintados pero te apetece probar algo diferente? ¿Hay días en los que no te decides entre un labial u otro? ¡Ponte los dos a la vez! La tendencia ombre lips vuelve con fuerza este verano (19/06/2016).

(29) Si esta es tu primera vez con los ombre lips, lo mejor es que pruebes con un degradado suave, dentro de la misma tonalidad de color. Una vez que ya tengas más práctica podrás probar con otros más atrevidos, que mezclen colores totalmente distintos (19/06/2016).

The following sub-sections will break down the corpus considering the three different sectors described, namely fashion, beauty and leisure.

\subsection{Fashion Anglicisms (33 cases)}

As reported by Lopriore and Furiassi (2015: 200), "the field of textiles and materials is highly technical, referential, exact, denotative and monosemous, with a limited communicative cycle. It is marked by borrowings from other languages."

The pure Anglicisms that fit within this category are the following: candy, chokers, cottage, dress code, front row, grills, jeans, layering, look, mix, nude, outfit, over size, sexy, shorts, slim, slip dress, soft, streetstyle, sweet, tip, top, trendy, tweed, working girl. There are also some adapted Anglicisms: bómber and tartán. Some false or pseudoAnglicisms also appear within this category: bombers, fashion, short, sport and teenager. Country chic is a hybrid Anglicism within this realm. 


\subsection{Beauty Anglicisms (23 cases)}

In this subsection, the following pure Anglicisms are included: baking, beauty, beauty youtubers, clown contouring, contouring, dot eyeliner, eyeliner, gloss, glowing hair, greenery, holographic lips, in-flight, influencer, makeup, nail art, piercing, pink lady, pink lips, rainbow hair, rainbow freckless and wire nail. Ombre lips, as explained above, is a hybrid Anglicism, as it combines a French term with an English term.

\subsection{Leisure Anglicisms (21 cases)}

The following list encompasses those Anglicisms that have been considered as belonging to the field of leisure since they are used to refer to free time and entertainment activities. These Anglicisms are afterwork (used as a noun, despite being used as an adjective like in English), after party, celebrity/celebrities/celebs, check out, cookies, foodie, gif, girls' night out, performance, phubbing, pop-up stores, rainbow food, room service, sane food, selfie, shopping, skyline, spa, welcome pack. There is also one case of an adapted Anglicism in this area, and one case of false Anglicism, reality.

In these specialised areas, the use of Anglicisms has different functions, as Rodríguez González (1996) ${ }^{2}$ reported two decades ago. The referential function, which denotes the literal meaning of a term, when applied to the use of Anglicisms in Spanish, may intend to fill a lexical gap whenever there is no suitable equivalent available. This is the case for lexical units like selfie.

The expressive function includes stylistically marked lexical units that normally have an emotive connotation. These Anglicisms usually have positive or negative connotations. Some words taken from this corpus could be regarded as fulfilling the function of attracting the audience, looking fashionable, cool and even snobbish. For example, look instead of apariencia; outfit/outfits instead of prendas, shorts rather than pantalones cortos, teenager instead of adolescente. All these Anglicisms, to list but a few, imply positive or fashionable nuances when used in Spanish.

Finally, Rodríguez González (1996) distinguishes another function; the textual one, or the capacity the language has to create text in relation to the context. For example, for the economy of language, as in the case of jeans to avoid saying pantalones vaqueros. ${ }^{3}$

\section{Conclusion}

This study is intended to reveal current trends about the use of Anglicisms in a specialized Spanish forum aimed mainly at women. After having carried out this 
analysis, the first hypothesis is confirmed: there is a tendency to use Anglicisms in the domains of fashion, beauty and leisure. The second hypothesis is also confirmed: nonadapted or pure Anglicisms, 66 in total, are by far more widespread than other types: false Anglicisms rank second, and adapted Anglicisms and hybrid Anglicisms last.

In terms of the subject area most likely to be affected by the use of Anglicisms, it is important to state that, due to the type of sources used for this research, in some cases, it is difficult to draw a line between beauty and fashion. The whole context of the post provided the clue to discern whether to include some Anglicisms in the fashion or beauty domains. However, as the third initial hypothesis predicted, fashion seems to be the area where most Anglicisms are found, followed by beauty and then leisure.

In a globalised world, hot-off-the-press English neologisms, such as phubbing, for instance, are immediately exported to other languages, without leaving sufficient time for proper translation. In addition, "the taste for the exotic" and "the charm of a foreign language" (Furiassi, 2010: 63) are important motivations for the use of Anglicisms, especially in domains such as fashion, beauty and leisure, which are intrinsically subject to constant change. French was traditionally the language associated with fashion until the 1980s, when English started replacing French as the language most frequently used to talk about fashion-related topics (fashion magazines, TV channels, social networks) (Lopriore and Furiassi, 2015: 203).

Despite the growing number of publications (Balteiro, 2011; Lopriore and Furiassi, 2015) dealing with Anglicisms in the specialised language of fashion, little attention has been paid so far to the analysis of the domains of beauty, fashion and leisure in online forums. The main purpose of this article has been to bridge this research gap and shed some light on the actual use of Anglicisms in this online medium, although its limitation lies in the analysis of one single Internet forum.

It is unquestionable that the contact between English and Spanish represents a cultural and linguistic enrichment for the recipient language, Spanish in this case. These linguistic changes, mostly visible at the lexical level, may also bring cultural changes in the way people understand and express certain concepts by using English rather than Spanish. The adoption of these lexical innovations mirrors the acceptance of cultural patterns typical of the donor language and culture. Therefore, the findings of this study suggest some reflections on the degree of exposure to the English language and the Anglo-American culture on the part of Spanish speakers. More precisely, these domainspecific Anglicisms may exert a noticeable influence and have subsequent long-term effects on the Spanish sense of identity. As Bloomfield (1933: 445-458) asserted, "every speech community learns from its neighbors" and, consequently, "cultural loans show what one nation has taught another".

As far as future research is concerned, it would be of utmost interest to analyse other Internet forums in order to check whether this tendency is similar in different Spanish forums.

\section{Notes}


1. When a term is assimilated, in Lorenzo's (1987) terminology, refers to a word has been completely accepted and naturalised in the recipient language, Spanish in this case, long time ago. Many of these terms have been included by DLE or are widely accepted and used by speakers of that RL.

2. Rodríguez González (1996) proved that Anglicisms in Spanish generally respond to specific functions, namely referential, expressive and textual.

3. As Rodríguez González (1996) stated in his categorisation, it is essential to notice that many of the lexical units compiled in this sample may fulfil more than one function.

4. I would like to thank the two anonymous reviewers who have given me valuable feedback on a previous version of this manuscript. Their useful and insightful comments have helped to improve this article.

\section{References}

Alfaro, Ricardo (1970): Diccionario de anglicismos. Madrid: Gredos.

Anderman, Gunilla, and Margaret Rogers, eds. (2005): In and Out of English: For Better, For Worse? Clevedon: Multilingual Matters.

Andersen, Gisle, Cristiano Furiassi and Biljana Mišić Ilić, eds. (2017): The Pragmatics of Borrowing: Investigating the Role of Discourse and Social Context in Language Contact [Special Issue]. Journal of Pragmatics, 113. Amsterdam: Elsevier.

Balteiro, Isabel (2011): "A few notes on the vocabulary of textiles and fashion". In I. Balteiro, ed., New Approaches to Specialized English Lexicology and Lexicography. Newcastle upon Tyne: Cambridge Scholars Publishing, 65-81.

Balteiro, Isabel and Miguel Ángel Campos (2012): "False anglicisms in the Spanish language of fashion and beauty". Ibérica, 24: 233-260.

Bloomfield, Leonard (1933): Language. New York: Henry Holt.

Campos-Pardillos, Miguel Ángel (2015): "All is not English that glitters: false anglicisms in the Spanish language of sports". Atlantis, 37(2): 155-174.

Crespo-Fernández, Eliecer (2015): Sex in Language: Euphemistic and Dysphemistic Metaphors in Internet Forums. London: Bloomsbury.

Crespo-Fernández, Eliecer and Carmen Luján-García (2013): “Anglicismo y tabú: valores axiológicos del anglicismo". Revista de Estudios Filológicos, 52: 53-74.

Crespo-Fernández, Eliecer and Carmen Luján-García (2017): “Anglicisms and word axiology in homosexual language". Revista Española de Lingüistica Aplicada (RESLA), 30(1): 74-102.

De Houwer, Annick and Antje Wilton, eds., (2011): English in Europe Today. Amsterdam and Philadelphia: John Benjamins.

Díez-Arroyo, Marisa (2016): "English words as euphemisms in Spanish fashion". English Today, 127(32/3): 30-39.

Fischer, Roswitha, and Hanna Pułaczewska, eds. (2008): Anglicisms in Europe. Linguistic Diversity in a Global Context. Newcastle Upon Tyne: Cambridge Scholars Publishing.

Furiassi, Cristiano (2010): False Anglicisms in Italian. Monza: Polimetrica.

Furiassi, Cristiano, Virginia Pulcini and Félix Rodríguez-González, eds. (2012): The Anglicization of European Lexis. Amsterdam and Philadelphia: John Benjamins.

Furiassi, Cristiano and Henrik Gottlieb, eds. (2015): Pseudo-English: Studies on False Anglicisms in Europe [Language Contact and Bilingualism 9]. Boston \& Berlin: De Gruyter Mouton. 
García-Morales, Goretti, Isabel González Cruz, Carmen Luján García and M $\mathrm{M}^{\mathrm{a}}$ Jesús Rodríguez Medina (2016): La presencia del inglés en la publicidad televisiva española (2013-2015). Madrid: Síntesis.

Garley, Matt and Julia Hockenmaier (2012): "Beefmoves: Dissemination, diversity, and dynamics of English borrowings in a German hip hop forum". Proceedings of the 50th Annual Meeting of the Association of Computational Linguistics. Jeju: Republic of Korea: 135-139. Available at http://www.aclweb.org/anthology/P12-2027 [accessed 29 September 2017].

González Cruz, $\mathrm{M}^{\mathrm{a}}$ Isabel, $\mathrm{M}^{\mathrm{a}}$ Jesús Rodríguez-Medina and $\mathrm{M}^{\mathrm{a}}$ Jesús Déniz-Santana (2009): Los anglicismos en el habla juvenil de Las Palmas de Gran Canaria. Madrid: La Factoría de Ediciones.

González Cruz, $\mathrm{M}^{\mathrm{a}}$ Isabel (2015): “Anglicising leisure: The multimodal presence of English in Spanish TV adverts". Calidoscopio, 13(3): 339-352.

Görlach, Manfred, ed. (2002): English in Europe. Oxford: Oxford University Press.

Graddol, David (2006): English Next. Plymouth: British Council.

Kachru, Braj (1992): "Teaching world Englishes". In B. Kachru, ed., The Other Tongue: English across Cultures. Chicago: University of Illinois Press, 355-366.

Lope Blanch, J.M (1977): “Anglicismos en la norma lingüística culta de México”. In J.M. Lope Blanch, ed., Estudios sobre el español hablado en las principales ciudades de América. México: UNAM, 271-279.

López-Zurita, Paloma (2005): "Economic anglicisms: Adptation to the Spanish linguistic system". Ibérica, 10: 91-114.

Lopriore, Lucilla and Cristiano Furiassi (2015): "The influence of English and French on the Italian language of fashion: Focus on false Anglicisms and false Gallicisms”. In C. Furiassi and H. Gottlieb, eds., Pseudo-English: Studies on False Anglicisms in Europe [Language Contact and Bilingualism 9]. Boston \& Berlin: De Gruyter Mouton, 197-226.

Lorenzo, Emilio (1987): “Anglicismos en la prensa". In Primera Reunión de Academias de la Lengua Española sobre El lenguaje y los medios de comunicación. Madrid: Real Academia Española, 71-79.

Luján-García, Carmen (2011): “English 'invasion' in Spain: An analysis of toys leaflets addressed to young children". English Today, 3: 3-9.

Luján-García, Carmen (2013): The English Language and the Anglo-American Culture: Its Impact on Spanish Language and Society. Newcastle upon Tyne: Cambridge Scholars Publishing.

(n.d.) Oxford Living Dictionaries. OLD. Available at https://en.oxforddictionaries.com/[accessed on 14 November 2017].

Pratt, Chris (1980): El anglicismo en el español peninsular contemporáneo. Madrid: Gredos.

Pulcini, Virginia, Cristiano Furiassi and Félix Rodríguez González (2012): "The lexical influence of English on European languages: From words to phraseology". In C. Furiassi, V. Pulcini and F. Rodríguez González, eds., The Anglicization of European Lexis. Amsterdam/Philadelphia: John Benjamins Publishing, 1-26.

Real Academia Española. 2014. DLE. Diccionario de la lengua española 23rd edition. Madrid: Real Academia Española. Available at http://dle.rae.es/ [accessed 26 September 2017].

Real Academia Española. 2005. DPD. Diccionario Panhispánico de Dudas. Madrid: Real Academia Española. http://www.rae.es/recursos/diccionarios/dpd (accessed 24 October 2017). 
Rodríguez Díaz, José Antonio (2011): Anglicismos y germanismos en el lenguaje de la publicidad del español peninsular contemporáneo 1998-2007. PhD dissertation, University of Santiago de Compostela.

Rodríguez González, Félix (1996): "Functions of Anglicisms in contemporary Spanish". Cahiers de Lexicologie. Revue Internationale de Lexicologie et Lexicographie, 68(1): 107128.

Rodríguez González, Félix (2011): Diccionario del sexo y el erotismo. Madrid: Alianza Editorial.

Rodríguez González, Félix (2012): “Anglicismos en el mundo del deporte: variación lingüística y sociolingüística.” Boletín de la Real Academia Española (BRAE)CXII (XXXVI): 261-285.

Rodríguez González, Félix (2013): "Pseudoanglicismos en español actual. Revisión crítica y tratamiento lexicográfico". Revista Española de Lingüística (RSEL), 43(1): 123-170.

Rodríguez González, Félix (2017): Gran diccionario de Anglicismos. Madrid: Arco Libros S.L. Rodríguez Medina, $\mathrm{M}^{\mathrm{a}}$ Jesús $\left(2016^{\mathrm{a}}\right)$ : "An approach to the study of the use of English in the Activities of Spanish Gyms". Spanish in Context, 13(1): 128-148.

Rodríguez Medina, $\mathrm{M}^{\mathrm{a}}$ Jesús (2016b): "The use of Anglicisms in Spanish television Commercials of cosmetics, hygiene and personal care products". Hermes Journal of Language and Communication in Business, 55: 157-169.

Tagliamnonte, Sali and Derek Denis (2008): "Linguistic ruin? Lol! Instant messaging and Teen Language". American Speech, 83(1): 3-34.

Tagliamonte, Sali (2016): "So sick or so cool? The language of youth on the Internet". Language in Society, 45(1): 1-32.

Zhang, Wei (2015): "Multilingual creativity on China's Internet". World Englishes, 34(2): 231246.

\section{Appendix}

\begin{tabular}{|l|l|l|l|l|}
\hline $\begin{array}{c}\text { Pure } \\
\text { Anglicisms }\end{array}$ & Freq. & Topics & \multicolumn{1}{c|}{ Pure Anglicisms in context } & $\begin{array}{c}\text { Spanish } \\
\text { equivalents }\end{array}$ \\
\hline After party & 1 & leisure & $\begin{array}{l}\text { Belleza after party: los mejores trucos para disimular } \\
\text { la resaca (28/11/2016) }\end{array}$ & $\begin{array}{l}\text { Evento en el que } \\
\text { personas que han } \\
\text { estado en una } \\
\text { fiesta se sientan a } \\
\text { charlar } \\
\text { relajadamente }\end{array}$ \\
\hline Baking & 2 & beauty & $\begin{array}{l}\text { Baking, el nuevo método de maquillaje (que } \\
\text { afortunadamente no implica meter la cabeza en el } \\
\text { horno) (21/07/2015) }\end{array}$ & $\begin{array}{l}\text { Método de } \\
\text { maquillaje }\end{array}$ \\
\hline Beauty & 3 & beauty & Trenzas corsé, la nueva obsesión beauty (04/05/2017) & Belleza \\
\hline
\end{tabular}




\begin{tabular}{|c|c|c|c|c|}
\hline $\begin{array}{l}\text { Beauty } \\
\text { youtubers }\end{array}$ & 1 & beauty & $\begin{array}{l}\text { Algunas beauty youtubers han visto aumentada su } \\
\text { popularidad gracias a tutoriales en los que explican } \\
\text { paso a paso cómo hacerte con esta } \\
\text { alocada tendencia. }(25 / 02 / 2016)\end{array}$ & $\begin{array}{l}\text { Personas que } \\
\text { realizan y suben } \\
\text { vídeos a } \\
\text { YouTube } \\
\text { relacionados con } \\
\text { la belleza, con } \\
\text { frecuencia trucos } \\
\text { de belleza }\end{array}$ \\
\hline Candy & 4 & fashion & $\begin{array}{l}\text { Candy rooms: los colores también son para el invierno } \\
(05 / 11 / 2015)\end{array}$ & Colores vivos \\
\hline $\begin{array}{l}\text { Celebrity / } \\
\text { Celebrities }\end{array}$ & 10 & leisure & $\begin{array}{l}\text { Pero como todas las semanas, aunque Kylie haya sido } \\
\text { la ganadora del título, otras celebrities también han } \\
\text { conseguido estar nominadas al peor look. }(14 / 06 / 2016)\end{array}$ & Famosos \\
\hline Celebs & 1 & leisure & $\begin{array}{l}\text { Como todas las semanas, aunque haya habido una } \\
\text { ganadora, hay otras celebs que también nos han } \\
\text { sorprendido con sus elecciones estilísticas. } \\
(17 / 03 / 2017)\end{array}$ & Famosos \\
\hline Check-out & 1 & leisure & $\begin{array}{l}\text { Desde que te reciben en recepción hasta que haces el } \\
\text { check out el equipo está pendiente de que no falte } \\
\text { nada, adelantándose incluso a tu mente }(09 / 06 / 2016)\end{array}$ & $\begin{array}{l}\text { Acción de salida } \\
\text { de un hotel o bien } \\
\text { comprar algún } \\
\text { producto }\end{array}$ \\
\hline Chokers & 2 & fashion & Accesorios: pendientes XXL y chokers (29/07/2016) & $\begin{array}{l}\text { Tipo de collar } \\
\text { femenino } \\
\text { ajustado al cuello }\end{array}$ \\
\hline $\begin{array}{l}\text { Clown } \\
\text { Contouring }\end{array}$ & 2 & beauty & $\begin{array}{l}\text { Después de la fiebre del contorneado que inició Kim } \\
\text { Kardashian hace un par de años, y del nuevo método } \\
\text { del clown contouring }(21 / 07 / 2015)\end{array}$ & $\begin{array}{l}\text { Maquillaje } \\
\text { femenino similar } \\
\text { al de un payaso }\end{array}$ \\
\hline Cookies & 1 & leisure & $\begin{array}{l}\text { Unas cookies calentitas para comenzar no están nada } \\
\text { mal. }(27 / 01 / 2017)\end{array}$ & Galletas \\
\hline Cottage & 2 & fashion & $\begin{array}{l}\text { Las claves para conseguir el estilo cottage } \\
\text { Que dinamizado con un aire casual da como resultado } \\
\text { el conocido estilo cottage que nos trasladará a las más } \\
\text { profundas campiñas inglesas }(18 / 08 / 2015)\end{array}$ & $\begin{array}{l}\text { Estilo de } \\
\text { decoración } \\
\text { campestre }\end{array}$ \\
\hline Contouring & 1 & beauty & $\begin{array}{l}\text { Desde el contouring hasta el strobing y por supuesto } \\
\text { los smokey eyes. }(14 / 06 / 2016)\end{array}$ & $\begin{array}{l}\text { Maquillaje que } \\
\text { realza los } \\
\text { contornos }\end{array}$ \\
\hline Dot eyeliner & 7 & beauty & $\begin{array}{l}\text { ¿Por qué el dot eyeliner es la tendencia beauty del } \\
\text { momento? }(31 / 01 / 2017)\end{array}$ & $\begin{array}{l}\text { Trazado con lápiz } \\
\text { de ojos con } \\
\text { puntos pequeños }\end{array}$ \\
\hline Dress code & 1 & fashion & $\begin{array}{l}\text { Otro elemento a tener en cuenta es saber si existe un } \\
\text { dress code fijado por los organizadores del evento en } \\
\text { cuestión y bien explicado }(03 / 01 / 2017)\end{array}$ & $\begin{array}{l}\text { Estilo de } \\
\text { vestimenta }\end{array}$ \\
\hline Eyeliner & 5 & beauty & $\begin{array}{l}\text { Eyeliner de unicornio, la magia llega a tus ojos } \\
(03 / 01 / 2017)\end{array}$ & Lápiz de ojos \\
\hline Foodie & 2 & leisure & $\begin{array}{l}\text { Si vives en una gran ciudad, no tienes tiempo que } \\
\text { perder para descubrir estos nuevos templos del } \\
\text { arte foodie }(02 / 12 / 2015)\end{array}$ & $\begin{array}{l}\text { Afición a la } \\
\text { comida y a la } \\
\text { bebida }\end{array}$ \\
\hline Front row & 1 & fashion & $\begin{array}{l}\text { Las modelos, diseñadores e invitadas del front row van } \\
\text { de fiesta en fiesta y nosotros no perdemos detalle de } \\
\text { sus mejores y peores looks }(24 / 02 / 2017)\end{array}$ & Primera línea \\
\hline Gif & 2 & leisure & $\begin{array}{l}20 \text { gifs de comida que te harán salivar de forma } \\
\text { inmediata. } \\
\text { Sigue leyendo y, sobre todo, mirando, porque estos }\end{array}$ & Imágenes \\
\hline
\end{tabular}




\begin{tabular}{|c|c|c|c|c|}
\hline & & & $\begin{array}{l}\text { gifs de comida son totalmente adictivos y generan } \\
\text { hambre de forma inmediata. } \\
(27 / 01 / 2017)\end{array}$ & \\
\hline $\begin{array}{l}\text { Girls' night } \\
\text { out }\end{array}$ & 1 & leisure & $\begin{array}{l}\text { Girls' night out! cosas que suceden después de una } \\
\text { noche de chicas }(16 / 11 / 2016)\end{array}$ & $\begin{array}{l}\text { Salida de chicas } \\
\text { por la noche }\end{array}$ \\
\hline Gloss & 3 & beauty & $\begin{array}{l}\text { Para unos labios llamativos y a todo color, píntalos } \\
\text { primero de un color a modo de base y repásalos con un } \\
\text { pincel para conseguir que esa tonalidad se vea } \\
\text { matizada por el gloss }(27 / 02 / 2017)\end{array}$ & Brillo labial \\
\hline Glowing hair & 1 & beauty & $\begin{array}{l}\text { Glowing hair, la nueva tendencia capilar que te hará } \\
\text { brillar en la oscuridad. }(12 / 01 / 2016)\end{array}$ & $\begin{array}{l}\text { Pelo muy } \\
\text { brillante }\end{array}$ \\
\hline Greenery & 2 & beauty & $\begin{array}{l}25 \text { imágenes que prueban que el greenery será el color } \\
\text { de tu maquillaje en } 2017(15 / 03 / 2017)\end{array}$ & De color verde \\
\hline Grills & 1 & fashion & $\begin{array}{l}\text { Cuando una chica normal se maquilla y arregla el pelo } \\
\text { con la plancha para salir con sus amigas, llega el clan } \\
\text { Jenner/Hadid y se ponen unos grills a medida. Se trata } \\
\text { de unas fundas de oro que se utilizaban en los años } 80 \\
\text { para decorar las dentaduras, que Madonna y Miley } \\
\text { Cyrus recuperaron hace unos años, y que hacía tiempo } \\
\text { que no veíamos. }(24 / 02 / 2017)\end{array}$ & $\begin{array}{l}\text { Fundas doradas } \\
\text { para los dientes }\end{array}$ \\
\hline $\begin{array}{l}\text { Holographic } \\
\text { lips }\end{array}$ & 2 & beauty & $\begin{array}{l}\text { Holographic lips, los labios también pueden brillar } \\
(27 / 02 / 2017)\end{array}$ & $\begin{array}{l}\text { Labios pintados } \\
\text { con motivos } \\
\text { holográficos }\end{array}$ \\
\hline Influencer & 1 & beauty & $\begin{array}{l}\text { Todo ha comenzado en el salón de belleza de Eun } \\
\text { Kyung Parkm, una auténtica influencer en el mundo de } \\
\text { la manicura (26/01/2017) }\end{array}$ & $\begin{array}{l}\text { Persona que } \\
\text { influye en el } \\
\text { mundo de la } \\
\text { moda }\end{array}$ \\
\hline In-flight & 1 & beauty & $\begin{array}{l}\text { In-flight essentials: básicos de belleza para sobrevivir } \\
\text { a un largo viaje de avión }(18 / 07 / 2016)\end{array}$ & En un vuelo \\
\hline Jeans & 2 & fashion & $\begin{array}{l}\text { El look estaba formado por una cazadora vaquera con } \\
\text { volumen en los hombros, unacamiseta de cuello alto } \\
\text { de rejillabajo otra de manga corta yunosjeans de tiro } \\
\text { alto con rayas laterales }(17 / 03 / 2017)\end{array}$ & $\begin{array}{l}\text { Pantalones } \\
\text { vaqueros }\end{array}$ \\
\hline Layering & 1 & fashion & $\begin{array}{l}\text { En esto consiste el layering, en llevar prendas de } \\
\text { diferentes longitudes al mismo tiempo. }(29 / 07 / 2016)\end{array}$ & $\begin{array}{l}\text { Estilo de } \\
\text { vestimenta con } \\
\text { varias capas de } \\
\text { ropa }\end{array}$ \\
\hline Look & 47 & fashion & $\begin{array}{l}\text { Con esta aplicación puedes confeccionar tus looks de } \\
\text { toda la semana. }(26 / 03 / 2015)\end{array}$ & $\begin{array}{l}\text { Imagen, } \\
\text { apariencia }\end{array}$ \\
\hline Makeup & 1 & beauty & $\begin{array}{l}\text { Ya sea a través de líneas de maquillaje con las mejores } \\
\text { firmas de cosmética o declarando que ellas mismas se } \\
\text { realizan sus makeup looks }(14 / 06 / 2016)\end{array}$ & Maquillaje \\
\hline Mix & 1 & fashion & $\begin{array}{l}\text { Nicki Minaj y su mix de tendencias, peor look de la } \\
\text { semana }(03 / 03 / 2017)\end{array}$ & Mezcla \\
\hline Nail art & 4 & beauty & $\begin{array}{l}\text { En Instagram lo puedes encontrar bajo el nombre de } \\
\text { wire nail art, algo así como nail art de alambre y } \\
\text { consiste en utilizar un fino hilo de alambre como base } \\
\text { de una manicura sencilla y efectiva. }(26 / 01 / 2017)\end{array}$ & $\begin{array}{l}\text { Tipo de } \\
\text { decoración de } \\
\text { uñas }\end{array}$ \\
\hline Nude & 3 & fashion & $\begin{array}{l}\text { Los tonos siempre entre el nude y el champán } \\
(14 / 06 / 2016)\end{array}$ & $\begin{array}{l}\text { Color natural de } \\
\text { la piel }\end{array}$ \\
\hline Outfit & 2 & fashion & $\begin{array}{l}\text { Natalia Vodianova a cometido un crimen estilístico } \\
\text { esta semana. Descubre quién es el culpable de que la } \\
\text { modelo vistiera de esta guisa y por qué nos ha }\end{array}$ & Ropa, vestimenta \\
\hline
\end{tabular}




\begin{tabular}{|c|c|c|c|c|}
\hline & & & defraudado tanto su outfit. (27/01/2017) & \\
\hline Over size & 1 & fashion & $\begin{array}{l}\text { La cantante eligió una chaqueta bomber rosa, una } \\
\text { camiseta over size a modo de vestido y unas botas } \\
\text { XXL. }(03 / 03 / 2017)\end{array}$ & $\begin{array}{l}\text { Talla grande. } \\
\text { Usada con el fin } \\
\text { de llevar la ropa } \\
\text { bastante holgada. }\end{array}$ \\
\hline Performance & 1 & leisure & $\begin{array}{l}\text { Tal vez la falta de libertad de entonces o de equidad en } \\
\text { los derechos homosexuales se suplía con imaginación, } \\
\text { carisma y performance descaradas }(27 / 06 / 2016)\end{array}$ & $\begin{array}{l}\text { Forma de } \\
\text { comportarse o } \\
\text { actuar }\end{array}$ \\
\hline Phubbing & 5 & leisure & $\begin{array}{l}\text { ¿Has oído hablar del phubbing? Es la palabra que } \\
\text { describe ese momento en el que descuidamos la } \\
\text { compañía humana solo para echarle un ojo al móvil } \\
\text { Nace como una combinación de dos términos } \\
\text { anglosajones: phone (teléfono) y snubbing (despreciar) } \\
(22 / 08 / 2016)\end{array}$ & $\begin{array}{l}\text { Ignorar la } \\
\text { presencia de } \\
\text { alguien en favor } \\
\text { de un teléfono } \\
\text { móvil }\end{array}$ \\
\hline Piercing & 3 & beauty & $\begin{array}{l}\text { Uñas con piercing, la última manicura viral de Kim } \\
\text { Kardashian }(31 / 01 / 2017)\end{array}$ & $\begin{array}{l}\text { Perforaciones en } \\
\text { la piel para } \\
\text { decorar }\end{array}$ \\
\hline Pink lady & 1 & beauty & $\begin{array}{l}\text { Ahora vas a saber según el color de tu piel, con qué } \\
\text { rosa lograrás destacar tus rasgos y convertirte en toda } \\
\text { una pink lady }(15 / 12 / 2016)\end{array}$ & $\begin{array}{l}\text { Mujer vestida y } \\
\text { maquillada de } \\
\text { rosa }\end{array}$ \\
\hline Pink lips & 1 & beauty & $\begin{array}{l}\text { ¿Vivan los pink lips! Elige tu rosa de labios perfecto } \\
(15 / 12 / 2016)\end{array}$ & $\begin{array}{l}\text { Labios de color } \\
\text { rosa }\end{array}$ \\
\hline Pop-up stores & 3 & leisure & $\begin{array}{l}\text { Las pop-up stores o tiendas efímeras cada vez están } \\
\text { más de moda y las marcas de champán se han dado } \\
\text { cuenta. }(10-10-2016)\end{array}$ & Tiendas efímeras \\
\hline $\begin{array}{l}\text { Rainbow } \\
\text { Food }\end{array}$ & 3 & leisure & $\begin{array}{l}\text { Rainbow Food: la comida como nunca antes la habías } \\
\text { visto. }(18 / 05 / 2016)\end{array}$ & $\begin{array}{l}\text { Comida con los } \\
\text { colores del } \\
\text { arcoiris a base de } \\
\text { colorantes }\end{array}$ \\
\hline Rainbow hair & 1 & beauty & $\begin{array}{l}\text { El rainbow hair ya no es solo cosa de chicas. Llega el } \\
\text { Merman Style }(26 / 06 / 2015)\end{array}$ & $\begin{array}{l}\text { Pelo decorado } \\
\text { con los colores } \\
\text { del arcoiris }\end{array}$ \\
\hline $\begin{array}{l}\text { Rainbow } \\
\text { freckless }\end{array}$ & 3 & beauty & $\begin{array}{l}\text { Llegan las rainbow freckless, mejillas a todo color! } \\
(25 / 02 / 2016)\end{array}$ & Pecas de colores \\
\hline Reality & 1 & leisure & $\begin{array}{l}\text { Tras el éxito de su reality, mamá Jenner no quiso dejar } \\
\text { pasar la ocasión y materializó la belleza de sus hijas } \\
\text { mayores }(14 / 06 / 2016)\end{array}$ & $\begin{array}{l}\text { Tipo de programa } \\
\text { televisivo }\end{array}$ \\
\hline Room Service & 1 & leisure & $\begin{array}{l}\text { ¿Un poco de hambre? ( ¡claro que sí, esto despierta el } \\
\text { apetito!) ¡Room service! Sin necesidad de levantarse, } \\
\text { caminar con los pies descalzos sobre el frío de la } \\
\text { cocina hasta la nevera. }(20 / 09 / 2016)\end{array}$ & $\begin{array}{l}\text { Servicio de } \\
\text { habitaciones }\end{array}$ \\
\hline Sane Food & 1 & leisure & Sane Food - Nutrición y Emoción (30/01/2017) & Comida sana \\
\hline Selfie & 2 & leisure & $\begin{array}{l}\text { Su palabra preferida es selfie y la mayor parte del } \\
\text { tiempo está posando }(31 / 10 / 2016)\end{array}$ & $\begin{array}{l}\text { Foto tomada a } \\
\text { uno mismo }\end{array}$ \\
\hline Sexy & 2 & fashion & $\begin{array}{l}\text { Gracias a su caída, la tonalidad y el escote en } V \text {, la } \\
\text { actriz consiguió un aspecto dulce y sexy a partes } \\
\text { iguales, muy a tono con su papel en el filme } \\
(03 / 02 / 2017)\end{array}$ & $\begin{array}{l}\text { Atractivo } \\
\text { sexualmente }\end{array}$ \\
\hline Shopping & 4 & leisure & $\begin{array}{l}\text { Celebra el Enfemenino Day con un shopping } \\
\text { apoteósico }(26 / 10 / 2015)\end{array}$ & Ir de compras \\
\hline
\end{tabular}




\begin{tabular}{|c|c|c|c|c|}
\hline Shorts & 1 & fashion & $\begin{array}{l}\text { Se llevan con faldas, shorts o mini vestidos fluidos. } \\
(09 / 02 / 2017)\end{array}$ & Pantalones cortos \\
\hline Skyline & 1 & leisure & $\begin{array}{l}\text { Aprovechas este momento del día para salir, tomarte tu } \\
\text { combinado favorito, charlar relajadamente y } \\
\text { simplemente disfrutar de las preciosas vistas del } \\
\text { skyline de la ciudad desde una terraza y sentirte un } \\
\text { poquito como la reina del mundo }(02 / 12 / 2015)\end{array}$ & Horizonte \\
\hline Slim & 1 & fashion & $\begin{array}{l}\text { El look compuesto por un vestido corto de cuadros } \\
\text { vichy, con capa del mismo estampado, pantalones de } \\
\text { piel de corte slim y botas de caña alta, no eran lo más } \\
\text { adecuado para esa tarde. }(27 / 01 / 2017)\end{array}$ & Esbelto, delgado \\
\hline Slip dress & 1 & fashion & $\begin{array}{l}\text { Kendall eligió un delicado slip dress y lo combino con } \\
\text { una sudadera de crochet con enormes borlones } \\
(24 / 02 / 2017)\end{array}$ & $\begin{array}{l}\text { Vestido de } \\
\text { tirantes }\end{array}$ \\
\hline Soft & 1 & fashion & $\begin{array}{l}\text { Existen muebles de estética "soft" que encajarán a la } \\
\text { perfección tanto en líneas puras como redondeadas. } \\
(05 / 11 / 2015)\end{array}$ & Suave \\
\hline$S p a$ & 1 & leisure & $\begin{array}{l}\text { Su concepto de Oenoterapia y Spa Sommelier te } \\
\text { permitirá probar algunos de sus vinos de la mano de un } \\
\text { experto, analizarlos y descubrir cuál es el que más te } \\
\text { gusta }(09 / 06 / 2016)\end{array}$ & $\begin{array}{l}\text { Lugar de } \\
\text { tratamientos } \\
\text { acuáticos } \\
\text { relajantes }\end{array}$ \\
\hline Streetstyle & 4 & fashion & $\begin{array}{l}\text { La hemos visto en la pasarela, el streetstyle y por } \\
\text { supuesto en las celebrities. }(08 / 02(2017)\end{array}$ & Estilo urbano \\
\hline Sweet & 1 & fashion & Muebles "sweet, sweet" (05/11/2015) & Dulce \\
\hline Tip & 2 & fashion & $\begin{array}{l}\text { Antes de seguir con los tips, te dejamos un shopping } \\
\text { con prendas y accesorios que pueden encajar para } \\
\text { distintos eventos formales }(03 / 01 / 2017)\end{array}$ & Truco \\
\hline Top & 1 & fashion & $\begin{array}{l}\text { Aún así, lo que logró llevarse toda la atención fue el } \\
\text { cinturón que Halsey llevó a modo de top. ¿Estaría } \\
\text { cómoda? Para combinarlo eligió una chaqueta larga } \\
\text { tipo impermeable y unos pantalones. (10/03/2017) }\end{array}$ & Camiseta \\
\hline Trendy & 1 & fashion & $\begin{array}{l}\text { Toma nota de nuestros consejos y serás la más trendy } \\
\text { de la temporada. }(29 / 07 / 2016)\end{array}$ & $\begin{array}{l}\text { De moda o } \\
\text { tendencia }\end{array}$ \\
\hline Tweed & 2 & fashion & $\begin{array}{l}\text { Tweed en el armario. El tejido favorito de Coco Chanel } \\
\text { arrasará esta temporada (20/08/2015) }\end{array}$ & Mezcla de lana \\
\hline Welcome pack & 1 & leisure & $\begin{array}{l}\text { Te obsequiarán con un welcome pack (no queremos } \\
\text { desvelar todas las sorpresas). }(26 / 10 / 2015)\end{array}$ & $\begin{array}{l}\text { Paquete de } \\
\text { bienvenida }\end{array}$ \\
\hline Wire nail & 1 & beauty & $\begin{array}{l}\text { Sin embargo cada vez son más las publicaciones web } \\
\text { que animan a que tú misma te hagas tus diseños wire } \\
\text { nail usando el típico alambre que se vende para hacer } \\
\text { pulseras y demás accesorios.(26/01/2017) }\end{array}$ & $\begin{array}{l}\text { Decoración de } \\
\text { uñas con } \\
\text { alambres }\end{array}$ \\
\hline Working girl & 1 & fashion & $\begin{array}{l}\text { Encontrarás los looks working girl más buscados. } \\
(22 / 11 / 2016)\end{array}$ & $\begin{array}{l}\text { Estilo para ir al } \\
\text { trabajo }\end{array}$ \\
\hline
\end{tabular}

Table 4: Non-adapted or pure Anglicisms compiled from enfemenino

\begin{tabular}{|c|c|c|c|c|}
\hline $\begin{array}{c}\text { Adapted } \\
\text { Anglicisms }\end{array}$ & Freq. & Topics & Adapted Anglicisms in context & Spanish equivalent \\
\hline
\end{tabular}




\begin{tabular}{|l|l|l|l|l|} 
Climax & 1 & leisure & $\begin{array}{l}\text { Utiliza alguna de estas canciones y el climax } \\
\text { está asegurado }(20 / 09 / 2016)\end{array}$ & Apogeo, culminación \\
\hline Tartán & 1 & fashion & Tartán pero en total look (20/08/2015) & $\begin{array}{l}\text { Tipo de tejido con } \\
\text { cuadrados tipo escocés }\end{array}$ \\
\hline
\end{tabular}

Table 5: Adapted Anglicisms compiled from enfemenino

\begin{tabular}{|c|c|c|c|c|c|}
\hline $\begin{array}{c}\text { False } \\
\text { Anglicisms }\end{array}$ & Freq. & Topic & False Anglicisms in context & Spanish equivalents & $\begin{array}{c}\text { Real English } \\
\text { equivalent }\end{array}$ \\
\hline Afterwork & 11 & leisure & $\begin{array}{l}\text { Con un ambiente relajado y una } \\
\text { conversación agradable no nos } \\
\text { cabe duda de que el afterwork es } \\
\text { el impulso que necesitas para } \\
\text { continuar con ánimo la semana. } \\
(02 / 12 / 2015)\end{array}$ & $\begin{array}{l}\text { Cóctel o copa que se } \\
\text { toma con los } \\
\text { compañeros de } \\
\text { trabajo tras una } \\
\text { jornada laboral }\end{array}$ & Afterwork party \\
\hline Bómber & 3 & fashion & $\begin{array}{l}\text { Por si no te has enterado, la } \\
\text { bómber es la chaqueta del } \\
\text { momento }(08 / 02 / 2017)\end{array}$ & Tipo de chaqueta & Bomber jacket \\
\hline Bombers & 1 & fashion & $\begin{array}{l}\text { Calcetines de rugby, bombers, } \\
\text { sweaters y abrigos acolchados te } \\
\text { vestirán de arriba abajo. } \\
(29 / 07 / 2016)\end{array}$ & Tipo de chaqueta & Bomber jacket \\
\hline Fashion & 3 & fashion & $\begin{array}{l}\text { Natalia Vodianova, apodada } \\
\text { Supernova, es una de las } \\
\text { supermodelos más conocidos del } \\
\text { mundo, su exitosa carrera y } \\
\text { pasión por la moda le han } \\
\text { convertido en un personaje clave } \\
\text { del panorama fashion al que } \\
\text { nunca le quitamos el ojo } \\
(27 / 01 / 2017)\end{array}$ & Moda & Fashionable \\
\hline Reality & 1 & leisure & $\begin{array}{l}\text { Tras el éxito de su reality, mamá } \\
\text { Jenner no quiso dejar pasar la } \\
\text { ocasión y materializó la belleza } \\
\text { de sus hijas mayores } \\
(14 / 06 / 2016)\end{array}$ & $\begin{array}{l}\text { Tipo de programa } \\
\text { televisivo }\end{array}$ & Reality show \\
\hline Short & 1 & fashion & $\begin{array}{l}\text { No podría faltar el ya } \\
\text { mencionado short en satén fucsia, } \\
\text { la camisa estampada, la cazadora } \\
\text { de ante con mangas de pelo... } \\
(28 / 10 / 2016)\end{array}$ & Pantalón corto & Shorts \\
\hline Sport & 1 & fashion & $\begin{array}{l}\text { Eso sí, hay que tener en cuenta el } \\
\text { diseño porque si es muy sport } \\
\text { serán más adecuadas para looks } \\
\text { informales. }(09 / 02 / 2017)\end{array}$ & Estilo deportivo & Sporty \\
\hline Teenager & 1 & fashion & $\begin{array}{l}\text { Todo muy teenager, para tener } \\
\text { contento a su público. }\end{array}$ & Adolescente & Teenage \\
\hline
\end{tabular}




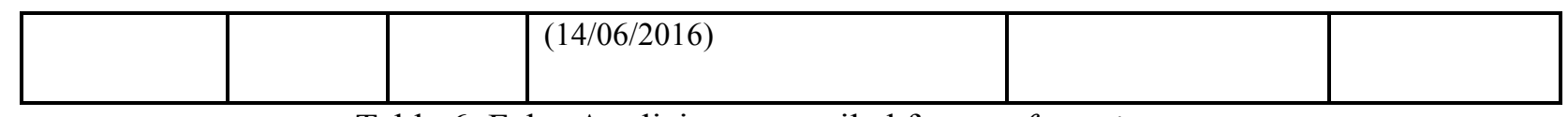

Table 6: False Anglicisms compiled from enfemenino

\begin{tabular}{|l|l|l|l|l|}
\hline $\begin{array}{c}\text { Hybrid } \\
\text { Anglicisms }\end{array}$ & Freq. & Topics & \multicolumn{1}{|c|}{ Hybrid Anglicisms in context } & Spanish equivalents \\
\hline Country chic & 1 & fashion & $\begin{array}{l}\text { Piezas chics que construyen los detalles de } \\
\text { este estilo evocando los ambientes más } \\
\text { románticos y bucólicos acercándose } \\
\text { incluso al county chic (18/08/2015) }\end{array}$ & Estilo de ropa \\
\hline Ombre lips & 3 & beauty & $\begin{array}{l}\text { Ombre lips: pásate al efecto degradado en } \\
\text { tus labios (19/06/2016) }\end{array}$ & $\begin{array}{l}\text { Labios maquillados con } \\
\text { pintura degradada }\end{array}$ \\
\hline
\end{tabular}

Table 7: Hybrid Anglicisms compiled from enfemenino 